\title{
EARNINGS MANAGEMENT AND AUDIT ADJUSTMENTS: AN EMPIRICAL STUDY OF IBEX 35 CONSTITUENTS
}

\author{
ORIOL AMAT*, OSCAR ELVIRA AND PETYA PLATIKANOVA
}

Abstract. Doubts about the reliability of a company's qualitative financial disclosure increase market participant expectations from the auditor's report. The auditing process is supposed to serve as a monitoring device that reduces management incentives to manipulate reported earnings. Empirical research confirms that it could be an efficient device under some circumstances and recognizes that our estimates of the informativeness of audit reports are unavoidably biased (e.g., because of a client's anticipation of the auditing process). This empirical study supports the significant role of auditors in the financial market, in particular in the prevention of earnings management practice. We focus on earnings misstatements, which auditors correct with an adjustment, using a sample of past and current constituents of the benchmark market index in Spain, IBEX 35, and manually collected audit adjustments reported over the 1997-2004 period (42 companies, 336 annual reports, 75 earnings misstatements). Our findings confirm that companies more often overstate than understate their earnings. An investor may foresee earnings misreporting, as manipulators have a similar profile (e.g., more leveraged and with lower sales). However, he may receive valuable information from the audit adjustment on the size of earnings misstatement, which can be significantly large (i.e., material in almost all cases). We suggest that the magnitude of an audit adjustment depends, other things constant, on annual revenues and free cash levels. We also examine how the audit adjustment relates to the observed market price, trading volume and stock returns. Our findings are that earnings manipulators have a lower price and larger trading volume compared to their rivals. Their returns are positively associated with the magnitude of earnings misreporting, which is not consistent with the possible pricing of audit information. Keywords: Audit adjustments, earnings management, market pricing of audit information. JEL: M41, M42. 


\title{
Earnings Management and Audit Adjustments: An Empirical Study of IBEX 35 Constituents
}

\author{
Oriol Amat ${ }^{1}$, Oscar Elvira and Petya Platikanova
}

\section{INTRODUCTION}

Nearly seven years after its collapse, Enron continues to fascinate those interested in earnings manipulation. Although Enron is the most popular example of fraudulent accounting disclosure, it is not clear what happened even after the court trials. Enron was permitted to book profits through means that were volatile and risky, but this specific activity did not break the law. So, how much of Enron's profits came from outright financial chicanery? And, how much profit resulted from exploiting accounting constructs such as mark-to-market accounting and the use of derivative instruments, which are legal and largely unregulated today?

The extent to which earnings are manipulated has long been of interest to analysts, legislators, researchers, and other investment professionals. Finding earnings manipulation is no small task, but despite the difficulties, the body of academic literature on the topic is growing. Today we would expect a company to manage earnings prior to its public securities' offering (Teoh, Welch and Wong, 1998) and when it is in financial distress (Beneish, 1997). Additionally, if a manager's compensation is strongly related to a company's profitability, we might be suspicious about the quality of financial results, especially if they seem to be extremely favorable (Healy, 1985).

When there are some doubts about the reliability of a company's qualitative financial disclosure, we may turn our attention to the auditor's report. In theory, the auditing process is supposed to serve as a monitoring device that reduces management incentives to manipulate reported earnings, as well as to detect earnings manipulation and misstatements. In practice, however, auditors may not be that efficient

\footnotetext{
${ }^{1}$ Contact author: Oriol Amat (oriol.amat@upf.edu). University Pompeu Fabra, Ramon Trias Fagras, 25-27, Barcelona 08005, Spain. All authors are from the University Pompeu Fabra (UPF)
} 
in enhancing the credibility of financial statements; the auditor-client relationship has peculiarities that could lead to a conflict of interest. Auditors may require an adjustment and a company to correct an earnings misstatement, but they are completely aware of the cost of these actions: An adjustment may strengthen an auditor's good reputation, but it would also reduce the auditors fee, which is usually a function of a company's size.

The conflict of interest in the auditor-client relationship casts doubt on the usefulness of external auditing. This empirical study contributes to the debate about the auditor's role in financial markets. It examines first the adjustments required by the auditor and relates them to the financial profile of an earnings manipulator. Then, it distinguishes the market consequences from earnings misstatements that have been made public with the audit adjustments, and concludes about the possible cost of this misstatement. Previous research can help us explain how large the earnings misstatement is on average, but not how it matches the profile of an earnings manipulator and if it has consequences on the stock exchange. This study sheds some light on the topic and concludes about the auditor's role in the efficient functioning of capital markets.

We manually collected earnings misstatements and audit adjustments from the annual reports of 42 public companies that previously or still constitute the benchmark stock market index of the Madrid Stock Exchange, IBEX 35. Our data is for the 1997-2004 period, with an overall number of 336 annual reports (75 earnings misstatements). Our findings suggest that an investor may foresee earnings misreporting, as manipulators have a similar profile (e.g., more leveraged and with lower sales). Additionally, earnings manipulators have a lower price and larger trading volume compared to their rivals. Their returns are positively associated with the magnitude of earnings misreporting, which is not consistent with the possible pricing of audit information.

The structure of the paper is as follows. In Section 2, we review previous studies of earnings management, and, more specifically, studies of the auditor's role and adjustments made. In this section, we 
also provide more details on existing findings about the market consequences of earnings manipulation. Section 3 focuses on the sample selection and presents the empirical design of our study. Empirical results comprise Section 4. Conclusions and implications follow in Section 5.

\section{LiterATURE SURVEY AND MOTIVATION}

The motivation for our study comes from two strains in the literature: 1) studies of earnings management, its detection by the auditor with required adjustments and 2) studies of the market consequences of the low-quality reported earnings.

2.1. Earnings Management and Audit Adjustments. Prior research suggests many reasons for earnings management, such as (1) capital market expectations and valuation, (2) contracts written in terms of accounting numbers, and (3) anti-trust or other government regulation (Healy and Wahlen, 1999). The empirical evidence is consistent with the idea that companies manage earnings to windowdress financial statements prior to the public securities' offering (Teoh, Welch and Wong, 1998) or for other reasons: to meet the expectations of financial analysts and investors or public earnings forecasts released by the management (Payne and Robb, 1997; Kasznik, 1999), to increase corporate managers' compensation and job security (Healy, 1985), to avoid violating lending contracts (Sweeny, 1994; Defond and Jiambalvo, 1994), and to reduce regulatory costs or increase regulatory benefits (Cahan, 1992; Jones, 1991).

For more than a decade, scholars have tried to distinguish managers motives for earnings misstatement. Previous studies argue that earnings smoothing is an earnings management practice that is more probable when a company's potential political costs, earnings variability and market risks are higher, and that managers smooth income using extraordinary items (Craig and Walsh, 1989). Additionally, several studies demonstrate that six proxies have explanatory power: size, risk, managerial compensation, leverage, and constraints on interest cover and dividend payout (Christie, 1990). Empirical results suggest that earnings manipulation is motivated by the desire to attract external financing at low cost (Dechow et 
al., 1996; results based on a sample of companies that were alleged to have violated generally accepted accounting principles, GAAP). Moreover, this desire for low-cost funding could be explained with the fact that earnings manipulators are usually younger, more levered growth companies that experienced poorer stock market performance, a decline in receivables and inventory turnovers, as well as a deterioration of gross margins and asset quality, with lower total accruals in the year of violation but positive accruals in the prior year (Beneish, 1997).

One of the challenges that this stream of research on earnings manipulation faces is the construct validity of the explanatory variables. Political and contracting costs affect a manager's decision to misstate current earnings. The measurement of these costs, however, remains an open issue. The size of a company is often included as a measure of political exposure. Nevertheless, it may well be introducing unspecified factor into the model(Christie, 1990). Additionally, there is a debate over the use of the leverage ratio as a proxy for contracting costs as it has been used by Leftwich (1981) and Holthausen (1981), since for other scholars this ratio measures 'closeness to covenants'.

The earnings management literature also debates the auditor's role in the prevention of misleading financial disclosure. With the adoption of the Sarbanes-Oxley Act in 2002, the interest in auditors and the quality of their statements as a monitoring mechanism in the financial reporting process has significantly increased. This regulatory change has motivated scholars to look further into the auditing process and its significant role in the capital market disclosure.

The audit-client relationship and the factors that contribute to the objective assessment of a company's financial reports have been extensively examined (e.g., the role of the audit committee; Wild 1996). Objective auditors can prevent excessive earnings management practice and this expected outcome from the auditing process has been the focus of a number of empirical studies. We can distinguish two main strains in this literature, which are classified according to their methodology: (1) Using a survey among audit partners and managers or data from laboratory experiments, some scholars examined attempted 
earnings management and the response to this practice in the audit firm. (2) Using archival data of adjustments introduced by the auditors in a company's annual financial results (i.e., the adjusting entry worksheet approach), others focused on real activities of earnings management.

The findings in these two strains of earnings management research do not greatly differ. Earnings overstatements are considered quite likely and earnings understatements are considered to be a strategy that retains maximum flexibility for future income-increasing attempts. Surveys confirm that imprecise standards and/or unstructured transactions help managers gain this reporting flexibility (Nelson, Elliot and Tarpley, 2002). Archival research on audit adjustments measures the likeliness of an over- or understatement and concludes on the overall effect from the auditing process. Surveys provide insights on the subjective judgments and management incentives for earnings management. Archival studies dispose of more objective data and make generalizations on which earnings management practice prevails and the driving factors.

Auditors typically collect information on misstatements, or 'audit differences' in individual items, and record them on a summary worksheet for possible financial statement adjustments. The auditor's adjusting entry worksheet can provide details on the real earnings management. Findings of nine studies on real audit adjustments confirm that in earnings manipulations pre-audit earnings and assets are more likely to be overstated, relative to their audited values. The reported average adjustments were between 1.6 percent and 4.6 percent of the total assets (Kinney and Martin, 1994). This empirical finding does not clearly confirm, however, that assets and earnings data are, on average, overstated, as it might be that auditors are simply directed towards detecting overstatement. Moreover, it might be that the large companies do not contribute to the results with a good number of audit adjustments. Because audit fees increase with client size, the probability an adjustment is not made increases with client size (Wright and Wright 1997). Larger clients are more likely to have the resources to structure transactions carefully 
and defend aggressive positions effectively, and auditors are more likely to require an adjustment to the earnings management attempts of their smaller clients (Nelson et al., 2002).

The archival data analysis has its advantage: It uses objective data. This, however, also has drawbacks. By construct, the data is unavoidably unbalanced. First, the data comes from client companies who anticipated the auditing process, and, hence, might have been more careful in preparing their financial statements than if they had not expected an audit. Second, misstatements may have been prevented because the client consulted the auditor about the proper accounting of a transaction prior to its initial recording and are, hence, not included in the empirical studies. And third, the data does not include errors that were made by the client, because they were detected by the auditor and corrected by the client before the years end. Moreover, errors or irregularities may not have occured because of the clientinitialed internal controls that were intended to reduce audit efforts and fees (See more details on the drawbacks of the archival approach in Kinney and Martin, 1994). Overall, these three drawbacks lead to an underestimation of the aggregate quantitative effect of auditing.

2.2. Market Response to Earnings Management. Capital markets react to new information. If the information is positive (negative) and concerns the fundamental value of the company, the price increase (decrease) is expected to be permanent. Financial analysts may partially anticipate good and bad news and this smoothes the market reaction to corporate announcements and events. When the information is anticipated, the price or volume reaction would not be significant on the announcement date. Rather, the price response would be observable before the disclosure day and the price adjustment would not be distinguishable from other information that would drive a security's price upward or downward. If the information has value-relevance and, additionally, is unexpected, then financial market participants would respond with a price revision immediately after the information release.

This knowledge about capital market reactions and sensitivity to expected and unexpected news helps scholars draw conclusions on the information content of the auditor's opinion. Empirical studies try 
to distinguish value-relevant information, if any, in the auditor's qualification, but this is not an easy task. The auditor's statement comprises a company's annual report, where the management discloses its current financial results and proposes their estimates of future revenues. Hence, it is difficult to disentangle which information drives the price response.

A price adjustment can occur not only because of unexpected reported earnings but also because of informative audit qualifications. Empirical findings suggest that the auditor's qualification could be a valuable signal, but it might not be timely. As audit qualifications are predominantly anticipated, it would seem that there is no new information given on the announcement day, i.e., the day of annual report release (Dodd, Dopuch, Holthausen, and Leftwich, 1986; Dopuch, Holthausen, and Leftwich, 1986). However, it could be that audit qualifications are partially unexpected. Empirical findings confirm that companies with audit qualification have a lower stock price response to earnings (Choi and Jeter, 1992), and this is consistent with the proposition of their value-relevance.

The research on the relation between the earnings response coefficient and audit qualification has its limitations, as suggested by Healy and Palepu (2001). However, empirical research on the association between audit qualifications and stock returns also confirms its main finding - a possible pricing of auditing information. Several empirical studies propose that investors perceive qualified audit reports as informative, as they respond negatively to audit qualifications (Dopuch et al., 1986; Choi and Jeter, 1992; Loudder et al., 1992).

\section{Hypothesis And Methodology}

This study contributes to the debate about how informative audit reports are. Prior research only examines the market response to audit qualifications. Besides their qualifications, however, auditors release additional information in some particular circumstances that may be highly informative about expected earnings manipulations - audit adjustments. 
Previous empirical studies have not addressed the market reaction to this information. This study focuses on the auditor's adjustments to reported earnings and measures the capital market response to corporate reports, which contain misreported earnings. If the earnings misstatement is expected, the audit adjustment should not surprise financial market participants. Public financial information, however, is not sufficient to indicate the direction and size of a possible earnings misreporting. Therefore, the audit adjustment may provide additional information to financial analysts and investors for their pricing decision.

We expect a significant difference in the market reaction to audit adjustments across companies. Our intuition is that financial market participants may have doubts about the truthfulness of financial reporting in particular circumstances. If the reporting company highly resembles the profile of a perfect manipulator, e.g., highly-leveraged and before public offering, then the information content of audit adjustments is likely to be lower. In contrast, if the company reports healthy profits over many years and suddenly the auditor announces its adjustments, the price reaction is expected to be significantly larger. For this reason, we first examine in the literature popular characteristics of an earnings manipulator to sketch the profile. Then, we compare our sample of public companies with audit adjustments to this ideal profile to conclude whether adjustment notification appears to surprise financial market participants. Additionally, we try to measure how sensitive the price reaction is to audit adjustments. We relate the size of earnings misstatements that have been corrected with the audit report to the observed market reaction. Previous studies have only documented how large the earnings misstatements are by using the audit adjustments and have not considered whether this audit information is valuable for stock pricing. This study sheds new light on the auditors role as a signal of financial information truthfulness.

Below, we elaborate on the 'ideal' profile of an earnings manipulator. Later in the section, we discuss our measurement of the price reaction and its relation with the audit adjustment. 
3.1. The 'ideal' earnings manipulator. Empirical findings in the literature on managerial incentives and earnings management allow us to sketch the ideal profile of an earnings manipulator. Numerous studies argue that agency costs, political costs, and the ownership structure are the most important variables that influence a manager's decision to misstate earnings (e.g., Beattie et al., 1994: Dechow et al., 1999).

We adopted the approach suggested by Dechow et al. (1999) in the measurement of these variables. We estimate agency costs of earnings management by dividend cover, leverage, and managerial holdings of share options. Based on findings of previous studies (Beattie et al., 1994), we expect that the association between earnings management and dividend cover is positive. As suggested in prior studies, earnings manipulations reduce the expected transaction costs associated with the funding of an uncovered dividend. Earnings manipulations are also more likely when the leverage increases: leverage proxies closeness to financial ratio covenants in debt agreements, earnings manipulations reduce the probability of breaching these covenants, and, as a result, reduce the expected costs of default and/or renegotiation. We measure leverage and relate it to audit adjustments and their size.

Previous studies have used information on managerial holding of shares as a proxy of agency costs. Unfortunately, we could not obtain this information for the complete period, but only for the last three years, due to data unavailability in Thomson Datastream. To conclude on the profile of an earnings manipulator and the price of audit adjustments with a larger sample, we excluded this variable from our empirical tests. In the robustness check, we included this variable in a regression analysis using the data only for the period 1992-1994. It has the expected positive sign, and its inclusion does not change our main empirical results and their interpretation.

Political costs are also expected to affect the probability of an earnings manipulation. As suggested by previous studies, the effect of political costs could be captured with the company's level of sales. This variable measures the potential political costs, born by the firm, and arising from the impact of 
external groups on the company's activities. We expect the costs of potential external intervention (from the government or the larger public) to motivate managers to engage in earnings management practice. Hence, greater earnings management is more likely for companies with higher expected political costs.

Additionally, earnings management is more likely when the financial year is difficult for the company. As suggested by Dechow et al. (1999), an earnings manipulator could have a high demand for funding, and may decide to raise capital issuing securities. We follow Dechow et al.s approach and measure the level of free cash and finance raised with a public offering. Table 1 provides more details on the variables and their measurement.

3.2. Market consequences: earnings misstatements and audit adjustments. For many years, research in accounting and finance has examined the response of financial analysts and investors to different corporate events (e.g., initial public offering) and public disclosure (e.g., earnings and dividend announcements). Scholars have drawn conclusions about the information content and significance of particular events using the price and volume reaction. Financial analysts and investors can consider the released information highly informative for their trading decisions. If the information is positive, a price increase would be expected. The price will increase more if the information signals very good future financial prospects and if it has not been predominantly unexpected.

The volume response to corporate disclosure and events, e.g., the earnings figures or the decision to initiate a stock split, can also reveal whether the financial market appreciates the management policy and its outcome: for instance, improved financial results. Empirical findings suggests that a more informative disclosure reduces the information asymmetry problem in financial markets. When the management releases highly informative financial and non-financial information, investors face lower adverse selection problems and this translates into improved liquidity, e.g., lower bid-ask spreads and larger trading volume.

In this study, we analyse the price and volume effects associated with the audit adjustment. Unfortunately, we could not obtain information on the exact date of the audit adjustment release. The audit 
reports and related adjustments comprise the annual report, which is often made public on a certain date. We do not have information on this date, which does not allow us to examine the price and volume change around the release date of the annual reports. Following other empirical studies, we focus instead on the long-term price effects. The short-term price response reveals the degree of surprise. The long-term price effect, measured by returns or cost of capital, however, can help us draw conclusions on the true market price of untruthful disclosure. Earnings manipulators could face worse conditions on the capital market, for instance through higher interest rates or higher cost of capital, when financial analysts and investors doubts the quality of their mandatory and voluntary disclosure.

We focus on the long-term price and volume effects from earnings manipulation revealed through audit adjustments. We first examine whether earnings manipulations have a significant effect on the price and trading volume. Then we relate the market returns to the audit adjustments and their size.

\section{SAMPLE SELECTION}

A number of empirical studies focus on earnings management that was alleged or detected (Feroz, Park and Pastena, 1991; Dechow, Sloan and Sweeney, 1996). These studies examine cases of earnings management using a special sample, namely companies under investigation by the U.S. SEC for earnings manipulation. Legal prosecution by the responsible authorities involves more extreme cases of earnings management, which was of interest in those studies. In contrast to the allegation studies, the audit-adjustment approach uses a more representative sample of companies, which allows researchers to conclude, among other things, how likely it is that management attempted to misstate earnings and whether an adjustment was required by the auditor.

We adopted the audit-adjustment approach with the purpose of distinguishing the profile of a company with earnings misstatements that were corrected by the auditor and to measure the capital market costs of this audit adjustment. We intend to capture the frequency and magnitude of earnings manipulations and related audit adjustments in large and highly traded companies on the stock exchange in Spain; 
thus, we decided to focus on those companies that previously or still constitute the benchmark stock market index of the Madrid Stock Exchange, IBEX 35, for the 1997-2004 period. Companies with the highest trading volume in euros over the previous six months are chosen for inclusion in the index, provided that the average free float market capitalisation of the stock is at least $0.3 \%$ of the total market capitalisation of the index, which was 527.6 billion euros in 2007. Hence, our sample is comprised of large cap companies whose adjustments in consolidated financial statements were required by the Big 4 auditors. We examined the annual reports of 42 companies during the 1997-2004 period, i.e., 336 audited reports (75 earnings misstatements). In the consolidated and unconsolidated financial results, we focused on earnings manipulations that were corrected with audit adjustments and manually collected this information. To relate the audit adjustments to the profile of the company, we obtained information on the possible determinants of earnings manipulation (the "motivation" variables), as defined in previous literature, from Thomson Datastream. We used the same source to collect information about the market reaction, or the "consequence" variables. Table 1 presents details on the variable definitions, predicted signs, and Thomson Datastream mnemonic.

We would like to clarify the terminology used in this study. When we discuss audit adjustments, we refer to adjustments introduced by external auditors, i.e., audit firms in the case of non-financial companies and the central bank in the case of index constituents from the financial sector. Later we related the magnitude of an audit adjustment to the profile of a typical earnings manipulator. In our sample there are companies which disclose audits adjustments for 2-3 consecutive years. However, we also have earnings misstatements corrected by the audit firm in a particular company for a particular year. In our discussion, we name the management of these companies in these period "earnings manipulators".

- Table 1 about here - 


\section{RESUlts}

5.1. A profile of an earnings manipulator with audit adjustments. Table 2 presents how likely, how often and how large earnings misstatements could be in our sample of IBEX 35 companies. The summary statistics suggest that it is more likely we will find an earnings overstatement than an earnings understatement. Prior research suggests that earnings understatements may help a manager change earnings expectations of financial analysts and investors and that they are more likely to occur around certain corporate events (e.g., CEO changes). We could not relate earnings understatements to important corporate news and in this study we only suggest that overstatements are more prevailing in our index sample.

- Table 2 about here -

Table 2 also presents how often an investor can find overstated earnings in the financial reports of representative companies of the Spanish financial market. Although in 1997 only $7 \%$ of all companies misreported their financial results, in 2001 and 2002 earnings management practice seems to have been more popular; about $40 \%$ of the sampled companies had an audit or other adjustment to their reported earnings. Moreover, the misstatement is far from insignificant. We use a popular measure to conclude on the materiality of this misstatement and consider it material when it is larger than $5 \%$ of total assets or of reported earnings without the audit adjustment. Descriptive results shows that a predominant part of earnings misstatements are material, and that earnings would have been on average about $30 \%$ lower if managers would not have been engaged in earnings management. In 2001, for instance, 4 out of 10 companies manipulated their financial performance; 9 out of 10 earnings misstatements were material and earnings would have been about $70 \%$ larger if external auditors - an audit company or the Central bank - did not adjust these attempts of earnings management.

Empirical findings of Table 2 reveal that public companies in the main market benchmark in Spain attempted to mislead financial market participants predominantly with overstated earnings. However, 
how is this related to the typical profile of an earnings manipulator and how predictable is an audit adjustment? It could be that investors expect misstated earnings, especially if reporting that a company experienced financial difficulties. Then, the adjustment introduced by external auditors should not be a surprise and the price response to this adjustment should not be significant.

Table 3 presents our findings on how typical the financial profile of an earnings manipulator is that constitutes the main market benchmark in Spain. We summarize six determinants of earnings management, as defined in Table 1, and conclude on the significant difference between earnings manipulators and other index constituents without earnings adjustments in a particular year. Additionally, we examine two popular financial ratios, namely earnings per share and the book-to-market ratio, to distinguish the profile of a company misreporting its financial performance. A positive difference across groups in this comparison verifies that a certain ratio, a determinant of earnings manipulations, has a lower value for earnings manipulators.

- Table 3 about here -

Empirical findings in Table 3 (Panel A) confirm that financial analysts and investors may be able to foresee an earnings misstatement if they carefully examine some financial ratios. Earnings manipulators are less likely to pay dividends; on aggregate, their dividends paid are about $0.06 \%$ of total assets. In contrast, index constituents without audit adjustments pay either larger dividends or more often; the ratio of dividends paid to total assets is about three times larger for them, i.e., dividends paid are $1.7 \%$ of total assets. Additionally, the leverage ratio may also signal that the probability of earnings misstatement is higher. Findings are consistent with previous literature that managers are likely to misstate financial results when leverage increases. Earnings manipulators are more leveraged than other index constituents without audit adjustments and the difference between the two groups is significant (at the $5 \%$ level). Debt comprises $80 \%$ of total assets for earnings manipulators; leverage is significantly lower if the company does 
not misreport financial performance before an external auditor corrects it with an adjustment (leverage ratio of 0.63$)$.

We may also expect earnings manipulations when sales are lower. Management can increase reported earnings using discretionary accruals and an auditor may intervene to correct for this misstatement. Findings confirm that earnings manipulators have significantly lower revenues when external auditors correct for possible misreporting. Sales are about $26 \%$ of total assets for earnings manipulators; the level of revenues is significantly larger for other index constituents (about twice as large, $52 \%$ of total assets). As earnings are predominantly overstated, market participants can expected management to misreport financial performance using income-increasing, discretionary accruals. A more thorough test is required to draw conclusions on the size of discretionary accruals when managers engage in earnings management.

Lower sales may explain not only the lower dividends pay by the earnings manipulator, but also suggest an explanation of a lower level of free cash available for debt repayment or investment projects. Findings suggest that the level of free cash is lower for index constituents with audit adjustments; the difference, however, is not significant. In contrast to other empirical studies, our findings suggest that the management of IBEX 35 companies do not engage in earnings management predominantly because of their need for funding. The funds raised in public offering are not significantly lower for earnings manipulators. It could be that financial analysts cannot distinguish between manipulated and nonmanipulated financial results. This would explain why earnings manipulators can raise funds that do not significantly differ from other index constituents without audit adjustments. Further tests are necessary, however, to conclude if this is a sign of mispricing.

Panel B of Table 3 contains results on the correlation between the size of the audit adjustment ("Magnitude") and the financial determinants of earnings management. As predicted, the association between an audit adjustment and the six financial ratios is positive. Larger adjustments are more likely when the agency and political costs are higher. Along with an increase in the leverage ratio, we can expect 
an increase in earnings misstatement, as measured by the size of the audit adjustment (i.e., correlation 0.071). More leveraged companies also are more likely to have larger earnings manipulations (i.e., correlation between leverage and magnitude: 0.118 ). Larger index constituents not only have larger political costs, as suggested in previous literature, but also larger audit adjustments. Findings suggest that larger companies are most likely to engage in earnings management, which is confirmed by the positive effect of political costs. Large companies also attract more attention from the media and analysts, which may affect a manager's decision to misstate reported accounting income; our empirical results, however, suggest that if this is a factor it should not determine earnings management practice in our sample of IBEX 35 index constituents.

The correlation matrix also presents interesting findings about the relationship among selected determinants. Empirical results confirm that more leveraged companies pay less dividends and that part of the explanation could be the lower level of free cash. Additionally, perhaps because of the lower sales, managers have less free cash for their ordinary investment decisions. If management decided to raise funds with public offering in order to dispose of more free cash, the result was not satisfactory. The relation between free cash and finance raised is negative and suggests that a public offering does not increase the free cash that management can use to pay dividends or invest in new projects.

The correlation table can only suggest if there is a significant relation between the audit adjustment and selected variables. The regression analysis, however, can confirm if, for instance, leverage would influence the presence of audit adjustments and if its effect would differ from the size effect. Table 4 presents our estimates. We first run a logit regression where the focus is on the presence of audit adjustment (the dependent variable is a dummy variable equal to 1 when there is an adjustment, 0 otherwise). Then, we take into account that audit adjustments differ in magnitude. We consider the audit adjustment differences and estimate the expected increase in the value of audit adjustments as a results of a marginal 
change, for instance, in leverage and size (the dependent variable in the multivariate regression analysis is continuous, namely the value of the audit adjustment relative to the total assets).

To examine the robustness of estimates, we include in the estimation equation additional variables and compare the model performance and sign/significance of regression coefficients across models 1,2 and 3. The difference between model 1 and model 2 is that the latter model includes year controls (a dummy variable for each year). The inclusion of the earnings-per-share and market value variables distinguish model 2 from model 3.

\section{- Table 4 about here -}

Our findings confirm that the dividend cover affects the probability of finding misreported earnings. The regression coefficient is significant and negative, contrary to our predicted sign. It is still an open debate in empirical research whether the association between earnings management and dividends paid should be positive or negative. A negative relation suggests that earnings manipulators pay less dividends in comparison to their rivals with more truthful financial disclosure. It could be that financial constraints do not give the freedom to companies with earnings misstatements to signal their favorable financial prospects with a dividend pay. This would be a valid explanation of our finding. However, it could be that a peculiarity in the dividend data drives this findings. There are many companies that prefer to reinvest their retained earnings rather than pay shareholder dividends.

When we compare the results across estimation models, we find that the significant role of dividends paid in earnings management prediction disappears if we control for market size and earnings-per share. The size of the company, measured by the market value, becomes significant. Large companies are more likely to pay dividends, which would explain our finding. The effect of dividends paid that we document in models 1 and 2 is simply captured in the size effect. In our sample, large companies are more likely to engage in earnings management. As previous studies argue, political costs could be behind this positive association. 
In the logit regression, we estimate how selected determinants would affect the probability of finding earnings misstatements and audit adjustments. To conclude on the relative importance of these determinants in the earnings management practice, we obtain estimates from the multivariate regression analysis. We have information on the actual size of audit adjustments and use this valuable information in the multivariate regression.

As predicted, we have a positive association between our set of dependent variables. The negative regression coefficient before finance raised and ex ante finance is not statistically significant. The relation between the magnitude of audit adjustment and dividends paid is not significant but positive, as documented in other studies (in contrast to the results obtained with the logit estimation procedure). In the eight-factor estimation model (model 3) only the size of sales explains any variance in the magnitude of audit adjustments. The sales effect differs from the size effect, as measured by the market value of a company. After controlling for dividends paid, leverage, profitability and finance, we can conclude that companies with higher sales are more likely to have larger audit adjustments.

The overall performance of our logit estimations significantly improves from model 1 to model 3. Our eight determinants of earnings management explain a large fraction of observed earnings misstatements that have been corrected with audit adjustments (i.e., the pseudo $R^{2}$ increases from $17.1 \%$ in model 1 to $29.5 \%$ in model 3 ). We document the same trend after comparing the predictive properties of the multivariate regression estimates. The explained variance, measured by adjusted $R^{2}$ consistently increases over the models. The eight-determinant model (model 3) explains about $10 \%$ of the variance in audit adjustments in our sample.

5.2. The price of audit adjustments. We examine the relation between the audit adjustment and the observed price effect on financial markets. Table 5 compares the change in price and traded volume across the two groups (earnings misstatements versus reported earnings without audit adjustments). Earnings manipulators have significantly lower market price and larger trading volume. It could be that 
the management engage in earnings management to mislead investors about future prospects of their company. However, it seems that these attempts do not lead to the desirable result, i.e., a higher price.

- Table 5 about here -

Descriptive statistics also suggests that the mean change in traded volume is significant across the groups. Previous literature suggests that a decrease in information asymmetry, which could be a result of more informative financial numbers for stock valuation decisions, would explain an increase in trading volume. Further empirical tests are necessary to conclude on whether there is a significant association between the market liquidity and audit adjustments. We can only document this significant difference and suggest that earnings manipulators have large trading volume. A plausible explanation would be that investors' disagreement around the true financial situation of a company with audit adjustments could also drive this large trading.

Table 6 contains our regression results. We estimate the association between stock returns and the magnitude of an audit adjustment. Contrary to our expectation, a decrease in the adjustment is associated with a decrease in realized market returns. This positive association remains significant even if we control for changes in trading volume (i.e., changes in stock returns as a result of liquidity effects), as the comparison between our models 1 and 2 reveals. If we consider that the year effect can also explain this relation (model 3), the marginal effect of an audit adjustment on stock returns (i.e., the regression coefficient) slightly decreases but still remains significantly different from zero. This positive association between earnings misstatement, measured with the size of audit adjustments, and subsequent stock returns is consistent with the possible earnings mispricing. If investors do not take into account that earnings numbers are overstated, as it turns to be, then their valuation models would provide more favorable estimates of the future financial prospect of a company. Hence, we would find market mispricing, i.e., a price that is high and its level cannot be explained with the fundamentals. To conclude on this 
possible mispricing, further checks are necessary. Future research may clarify if an arbitrager can correct for this mispricing and, if an arbitrage strategy is efficient, why he does not execute it.

- Table 6 about here -

\section{Conclusions}

Empirical research confirms that the auditing process could be an efficient device under some circumstances and recognizes that our estimates of the usefulness of audit reports are unavoidably biased (e.g., because of a client's anticipation of the auditing process). This empirical study supports the significant role of auditors in the financial market, in particular in the prevention of earnings management practice. We examine on earnings misstatements and manually collected audit adjustments using a sample of past and current constituents of the benchmark market index in Spain, IBEX 35. (1997-2004 period, 42 companies, 336 annual reports, 75 earnings misstatements). Our findings confirm that companies more often overstate than understate their earnings and that the overstatement is not only large but also material in almost all the cases. We document a large number of material misstatements in 2001, when 4 out of 10 companies manipulated their financial results ( earnings would have been about $70 \%$ larger if external auditors did not adjust these attempts of earnings management).

Additionally, we relate audit adjustments to selected financial characteristics which, as previous literature suggests, can explain earnings management (e.g., leverage and sales growth). We confirm that an investor may foresee earnings misreporting, as manipulators have a similar profile (e.g., more leveraged and with lower sales). However, we argue that he may find valuable information in the audit report, as the magnitude of an adit adjustment reveals how large earnings misstatement are. Our findings confirm that the magnitude of an audit adjustment depends, other things constant, on annual revenues and free cash levels.

Moreover, we also examine how the audit adjustment relates to the observed market price, trading volume and stock returns. Our findings are that earnings manipulators have a lower price and larger 
trading volume compared to their rivals. Their returns are positively associated with the magnitude of earnings misreporting, which is not consistent with the possible pricing of audit information.

Several issues connected to the positive relation between the audit adjustment and stock returns deserve further attention. The audit adjustment verifies that the management attempted earnings management. Hence, the positive relation is consistent with earnings mispricing. However, the adjustment also corrects for the reporting bias and, as a result, certifies that the adjusted earnings are more conservative and truly reflect the financial position of a company. Thus, this may also explain the unexpected significant positive association between the audit adjustment and stock returns. Further empirical tests are necessary to conclude on the investor's positive perception of audit adjustments. There are various measure of earnings quality which, once obtained, could be related to the audit reports and related adjustments. 


\section{REFERENCES}

Beattie, V., S. Brown, D. Ewers, B. John, S. Manson, D. Thomas, and M. Turner. 2002. "Extraordinary Items and Income Smoothing: A Positive Accounting Approach." Journal of Business Finance and Accounting, vol. 21, no. 6: 791-811.

Beneish, M. 1997. "Detecting GAAP Violation: Implications for Assessing Earnings Management Among Firms with Extreme Financial Performance." Journal of Accounting and Public Policy, vol. 16: 271-309.

Cahan, S. 1992. "The Effect of Antitrust Investigation on Discretionary Accruals: A Refined Test of the Political Cost Hypothesis." Accounting Review, vol. 67: 77-95.

Christie, A. 1990. "Aggregation of Test Statistics: An Evaluation of the Evidence on Contracting and Size Hypotheses." Journal of Accounting and Economics, vol. 12, no. 1: 15-36.

Choi, S., and D. Jeter. 1992. "The Effects of Qualified Audit Opinions on Earnings Response Coefficients." Journal of Accounting and Economics, vol. 15, no. 2-3: 229-247.

Craig, R., and P. Walsh. 1989. "Adjustments For 'Extraordinary Items' In Smoothing Reported Profits of Listed Australian Companies: Some Empirical Evidence." Journal of Business Finance and Accounting, vol. 16, no. 2: 229-245.

Dechow, P., R. Sloan, and A. Sweeney. 1996. "Causes and Consequences of Earnings Manipulation: An Analysis of Firms Subject to Enforcement Actions by the SEC." Contemporary Accounting Research, vol. 13 , no. 2: 1-47.

Defond, M., and J.Jiambalvo. 1994. "Debt Covenant Violation and Manipulation of Accruals." Journal of Accounting and Economics, vol. 17: 145-176.

Dodd, P., N. Dopuch, R. Holthausen, and R. Leftwich. 1984. "Qualified Audit Opinions and Stock Prices." Journal of Accounting and Economics, vol. 6: 3-38. 
Dopuch, N., R. Holthausen, and R. Leftwich. 1986. "Abnormal Stock Returns Associated with Media Disclosures of 'subject to' Qualified Audit Opinions." Journal of Accounting and Economics, vol. 8: 93-117.

Feroz, E., K. Park, and V. Pastena. 1991. "The Financial and Market Effects of the SEC's Accounting and Auditing Enforcement Releases." Journal of Accounting Research, vol. 29: 107-142.

Firth, M. 1978. "Qualified Audit Reports: Their Impact on Investment Decisions." Accounting Review, vol. 53: $642-650$.

Healy, P., and K. Palepu. 2001. "Information Asymmetry, Corporate Disclosure, and the Capital Markets: A Review of the Empirical Disclosure Literature." Journal of Accounting and Economics, vol. 31, no. 1-3: 405-440.

Healy, P., and J. Wahlen. 1999. "A Review of the Earnings Management Literature and its Implications for Standard Setting." Accounting Horizons, vol. 13, no. 4: 365-383.

Holthausen, R. 1981. "Evidence on the Effect of Bond Covenants and Management Compensation Contracts on the Choice of Accounting Techniques. The Case of the Depreciation Switch-back." Journal of Accounting and Economics, vol. 3, no. 1: 73-109.

Jones, J. 1991. "Earning Management During Import Relief Investigation." Journal of Accounting Research, vol. 29: 193-228.

Kasznik, R. 1999. "On the Association between Voluntary Disclosure and Earnings Management." Journal of Accounting Research, vol. 37, no. 1: 5781.

Kinney, W., and R. Martin. 1994. "Does Auditing Reduce Bias in Financial Reporting? A Review of Audit-Related Adjustment Studies." Auditing: A Journal of Practice and Theory, vol. 13, no. 1: $149-156$.

Leftwich, R. 1981. "Evidence of the Impact of Mandatory Changes in Accounting Principles on Corporate Loan Agreements." Journal of Accounting and Economics, vol. 3, no. 1: 3-36. 
Loudder, M., I. Khurana, R. Sawyers, C. Cordery, C. Johnson, J. Lowe, and R. Wunderle. 1992. "The Information Content of Audit Qualifications." Auditing: A Journal of Practice and Theory, vol. 11, no. 1: 69-82.

Nelson, M., J. Elliott, and R. Tarpley. 2002. "Evidence from Auditors about Managers' and Auditors' Earnings Management Decisions.” Accounting Review, vol. 77: 175202.

Payne, J., and S. Robb. 1997. "Earnings Management: The Effect of Ex-ante Earnings Expectations." Working Paper, University of Oklahoma, Norman.

Sweeny, A. 1994. "Debt Covenant Violations and Managers' Accounting Responses." Journal of Accounting and Economics, vol. 17: 281-308.

Teoh, S., I. Welch, and T. Wong. 1998. "Earnings Management and the Long-Run Market Performance of Initial Public Offerings." Journal of Finance, vol. 53, no. 6: 1935-1974.

Wild, J. 1996. "The Audit Committee and Earnings Quality." Journal of Accounting, Auditing 6 Finance, vol. 11, no. 2: 247-287.

Wright, A., and S. Wright. 1997. "An Examination of Factors Affecting the Decision to Waive Audit Adjustments." Journal of Accounting, Auditing \& Finance, vol. 12, no. 1: 15-36. 
Table 1 Determinants of Earnings Management: Definition and Predicted Sign

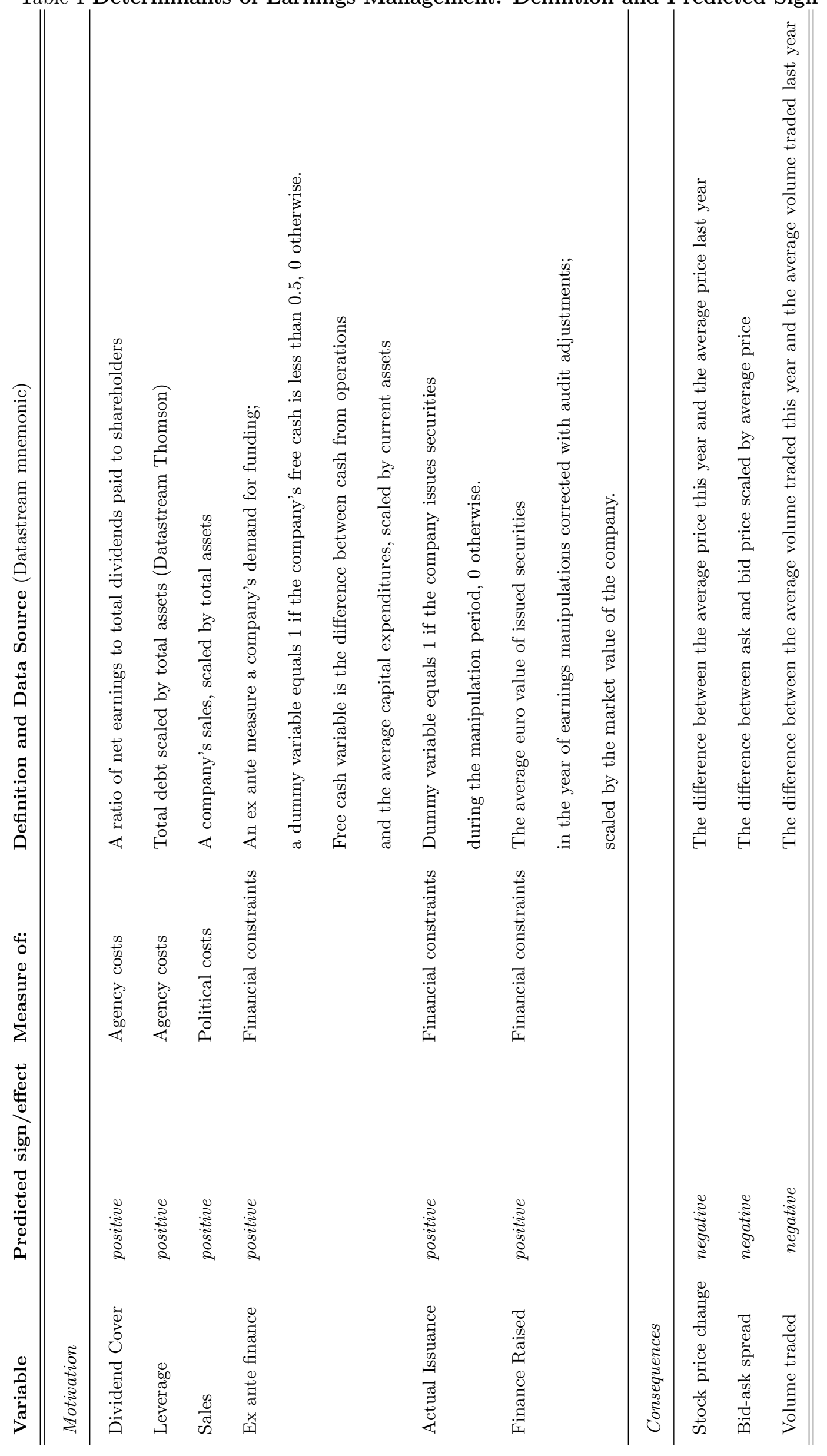


Table 2

Earnings misstatements: summary

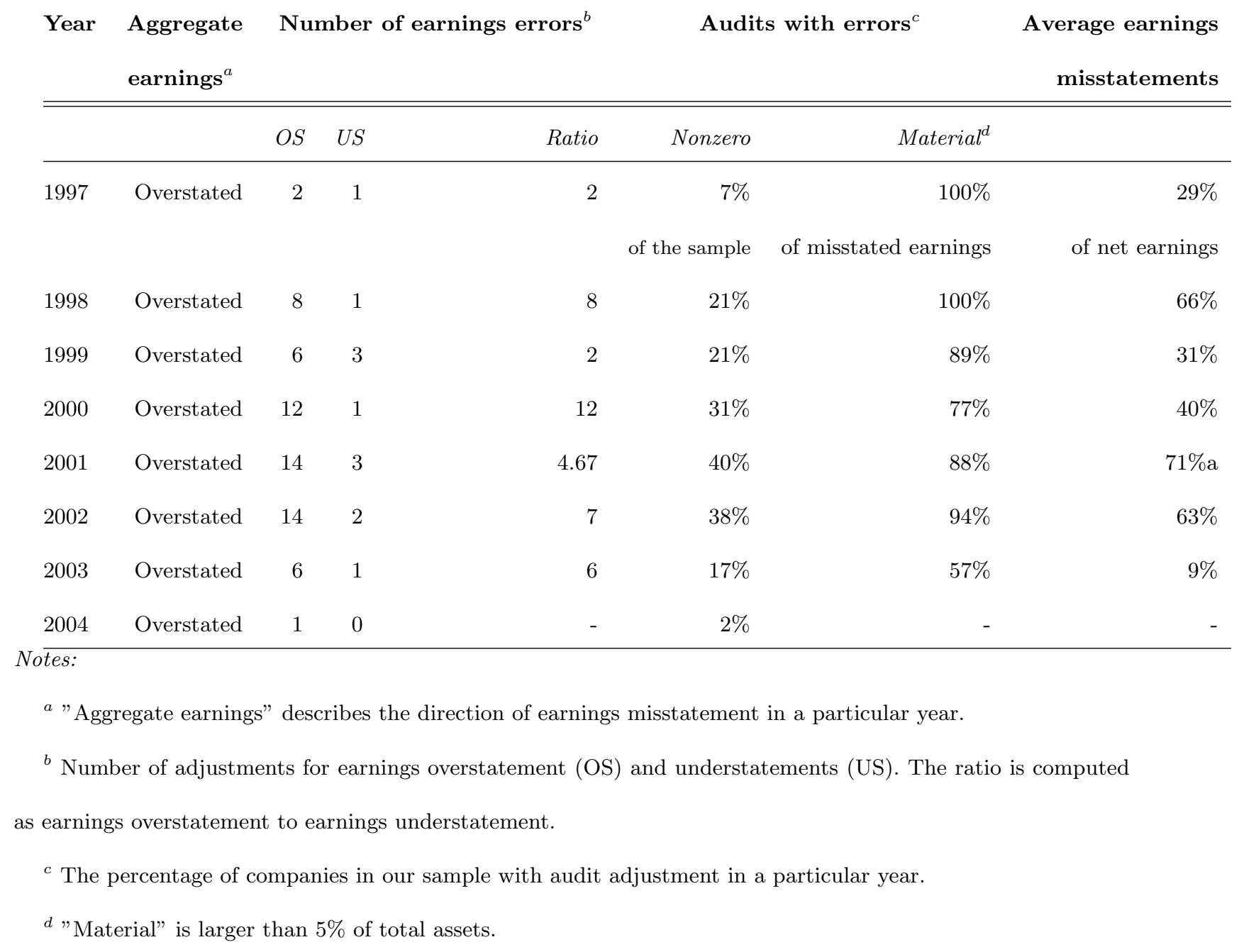


Table 3

\section{Descriptive Statistics: Determinants of Earnings Management}

Panel A: Descriptive statistics

\begin{tabular}{|c|c|c|c|c|c|c|}
\hline & Mean & St.Dev & Min & Max & \multicolumn{2}{|c|}{ Difference in the mean } \\
\hline Determinants of earnings manipulations & & & & & T-test & P-value \\
\hline Dividend cover & 0.014 & 0.026 & 0.000 & 0.300 & 2.82 & 0.00 \\
\hline Leverage & 0.668 & 0.021 & 0.078 & 0.953 & 5.57 & 0.00 \\
\hline Sales & 0.468 & 0.406 & 0.009 & 1.960 & 4.07 & 0.00 \\
\hline Free cash & 0.125 & 0.813 & -5.673 & -5.673 & 0.67 & 0.51 \\
\hline Financed raised & 0.077 & 0.185 & 0.000 & 0.185 & 0.01 & 0.99 \\
\hline \multicolumn{7}{|l|}{ Financial ratios } \\
\hline Earnings per share & 0.873 & 2.001 & -1.035 & 30.650 & 1.43 & 0.15 \\
\hline Book-to-Market value & 3.104 & 3.133 & 0.877 & 14.880 & 4.53 & 0.00 \\
\hline
\end{tabular}

\begin{tabular}{|c|c|c|c|c|c|c|}
\hline & Magnitude & Dividend cover & Leverage & Sales & Free cash & Financed raised \\
\hline Magnitude & 1 & & & & & \\
\hline Dividend cover & 0.071 & 1 & & & & \\
\hline Leverage & 0.118 & -0.215 & 1 & & & \\
\hline Sales & 0.157 & 0.049 & 0.195 & 1 & & \\
\hline Free cash & 0.053 & 0.237 & -0.294 & -0.180 & 1 & \\
\hline Finance raised & 0.042 & -0.103 & 0.046 & 0.079 & -0.039 & 1 \\
\hline
\end{tabular}


Table 4

\section{Regression results. Dependent variable: An Audit Adjustment ${ }^{a}$}

\begin{tabular}{|c|c|c|c|c|c|c|}
\hline \multicolumn{3}{|c|}{ Logit } & \multicolumn{4}{|c|}{ Multivariate regression } \\
\hline & $\left(1^{b}\right)$ & $(2)$ & (3) & (1) & $(2)$ & (3) \\
\hline \multirow[t]{2}{*}{ Dividend cover } & -53.17 & -42.55 & -34.95 & 0.55 & 0.14 & 0.31 \\
\hline & $\left(2.09^{*}\right)$ & $\left(1.55^{* * *}\right)$ & $(1.29)$ & $(0.32)$ & $(0.08)$ & $(0.18)$ \\
\hline \multirow[t]{2}{*}{ Leverage } & 3.80 & 4.39 & 4.23 & 0.09 & 0.08 & 0.12 \\
\hline & $\left(3.13^{*}\right)$ & $\left(3.3^{*}\right)$ & $\left(2.88^{*}\right)$ & $(0.5)$ & $(0.43)$ & $(0.6)$ \\
\hline \multirow[t]{2}{*}{ Sales } & -2.13 & -2.46 & -2.16 & 0.27 & 0.26 & 0.23 \\
\hline & $\left(2.70^{*}\right)$ & $\left(2.83^{*}\right)$ & $\left(2.56^{*}\right)$ & $\left(2.40^{*}\right)$ & $\left(2.18^{*}\right)$ & $\left(1.85^{*}\right)$ \\
\hline \multirow[t]{2}{*}{ Ex ante finance } & 0.99 & 0.99 & 0.99 & -0.19 & -0.18 & -0.17 \\
\hline & $\left(1.86^{* *}\right)$ & $\left(1.65^{* *}\right)$ & $\left(1.56^{* *}\right)$ & $\left(2.00^{*}\right)$ & $\left(1.78^{* *}\right)$ & $(1.60)$ \\
\hline \multirow[t]{2}{*}{ Issuance } & -0.42 & -0.59 & -0.87 & -0.01 & 0.02 & 0.04 \\
\hline & $(0.80)$ & $(1.06)$ & $(1.47 * * *)$ & $(0.14)$ & $(0.21)$ & $(0.39)$ \\
\hline \multirow[t]{2}{*}{ Finance raised } & 0.94 & 1.40 & 1.20 & 0.04 & -0.05 & -0.05 \\
\hline & $(0.70)$ & $(0.91)$ & $(0.71)$ & $(0.16)$ & $(0.18)$ & $(0.22)$ \\
\hline \multirow[t]{2}{*}{ EPS } & & & -0.42 & & & 0.05 \\
\hline & & & (1.22) & & & $(0.98)$ \\
\hline \multirow[t]{2}{*}{ Market value } & & & 0.04 & & & -0.01 \\
\hline & & & $\left(2.42^{*}\right)$ & & & $(0.51)$ \\
\hline Year control & no & yes & yes & no & yes & yes \\
\hline Pseudo $R^{2} / R^{2}$ & $17.1 \%$ & $25.7 \%$ & $29.5 \%$ & $4.1 \%$ & $8.8 \%$ & $9.5 \%$ \\
\hline
\end{tabular}

Notes: ${ }^{a}$ The table presents regression results. The logit regression has been performed with a dummy variable:

1 if the company attempted to misstate its earnings and an audit adjustment was reported, 0 - otherwise. The multivariate regression has a dependent variable the magnitude of this audit adjustment.

${ }^{b}$ The difference between the three models is in the number of variables and the included controls. 
Table 5

Market variables. Difference across groups

\begin{tabular}{lcc} 
& $\begin{array}{c}\text { Earnings manipulators } \\
\text { (For }=1)\end{array}$ & $\begin{array}{c}\text { Earnings non-manipulators } \\
\text { For }=0)\end{array}$ \\
\hline \hline Price change & 0.049 & -0.05 \\
$N^{b}$ & 138 & 46 \\
Volume & 0.043 & 0.34 \\
$N$ & 144 & 54 \\
\hline \hline
\end{tabular}

Notes: ${ }^{a}$ The test is on the significance of the mean difference in price change and volume traded. We compare

earnings manipulators to their rivals without reported audit adjustments. The difference is significant at the $1 \%$

level $(*)$ and at the $5 \%$ level $(* *)$.

${ }^{b} N$ denotes the number of observations.

Table 6

Regression results. Dependent variable: Raw returns (GLS regression)

Variable/Model

Magnitude Adj.

Change Volume

Year control

no

$5.87 \%$

$R^{2}$
(2)

0.15

0.09

$\left(2.34^{*}\right)$

$-0.08$

$-0.05$

$\left(1.66^{*}\right)$

no

yes

$7.29 \%$

$23.39 \%$ 